\title{
Effect of Organic Additives on Vegetation of Plants Grown in Landfill Soil after Ozokerite Processing
}

\author{
Jan Gąsior ${ }^{1 *}$, Stanisław Wlaśniewski ${ }^{1}$, Inesa Drozd ${ }^{2}$, \\ Halyna Kreczkiwska ${ }^{2}$, Malgorzata Nazarkiewicz ${ }^{1}$ \\ ${ }^{1}$ Department of Soil Science, Environmental Chemistry and Hydrology, University of Rzeszów, \\ Zelwerowicza 8b, 35-601 Rzeszów, Poland \\ ${ }^{2}$ Department of Biology and Chemistry, Pedagogical State University in Drohobych, \\ Szewczenka 23, 82-100 Drohobych, Ukraine
}

Received: 20 January 2016

Accepted: 11 June 2016

\begin{abstract}
Our research was carried out on landfill soil after mining and processing the unique mineral ozokerite (earthwax) in Borysław, Ukraine, where natural sodding has not appeared for many years. The strict micro-plot experiment in the split-plot design was set using four organic additives (manure OB, substrate after champignon cultivation PP, municipal sewage sludge OK, and sawdust $\mathrm{T}$ ), each in the amount of 4,8 , and $12 \%$ as compared to the control, as well as the third factor of test plants (white lupine, Italian ryegrass, cocksfoot, and pink clover). Our paper presents the course of plant vegetation and weight of fresh aboveground parts in the year of organic components application for the preliminary experiment and during the consequent experiment. The use of manure on the landfill ground accelerated vegetation of seedlings [phase 12] in relation to the control by seven days and substrate after champignon cultivation and municipal sludge by three days (in proportion to the introduced dose). Furthermore, the additives increased plant density. The use of sawdust did not affect the plant growth rate in this phase, and even caused a slight setback in the number of plants per plot. Plants from the preliminary experiment showed higher growth dynamics and a longer growing season under the influence of the components used: $\mathrm{OB}>\mathrm{PP}>\mathrm{OK}$. The consequent effect of the applied components (OB, PP, and OK) on plant vegetation was weaker. The use of sawdust resulted in the forfeiture of all plant species during winter. In the consequent experiment, the yield of green mass of the aboveground parts of plants depended on the type and dose of organic additives, and it was a good indicator of the phyto-remediation features of used species. The largest weight of the aboveground parts of plants $\left(1,233\right.$ and $1,168 \mathrm{~g} / \mathrm{m}^{2}$, from cocksfoot and pink clover, respectively) was achieved on the landfill soil with $12 \%$ manure addition.
\end{abstract}

Keywords: plant growth phase, chlorophyll content, fresh weight yield, efficiency of additives

*e-mail:kgchsih@univ.rzeszow.pl 


\section{Introduction}

The surface of a landfill, inactive for more than 20 years after mining and purifying the unique mineral ozokerite (earthwax) in the center of Borysław, Ukraine, is not covered with any vegetation. That affected area interrupts the functional continuity of the city and is a source of annoying dust. The ground of the landfill contains solid waxes, polycyclic aromatic hydrocarbons (PAHs), and other petroleum substances that do not constitute a serious threat to the environment [1]. The literature suggests that such a mixture of different PAHs and their derivatives are characterized by highly hydrophobic and lipophilic features [2-3], as well as an ability to adsorb non-polar particles, which affects the water-air properties of the soil [4]. Moreover, hydrocarbons make the increased total carbon content along with enhancement in the $\mathrm{C}: \mathrm{N}$ ratio [5], destabilize the colloids, and worsen the soil structure, therefore resulting in higher soil compactness [6-8].

On the landfill surface, the process of spontaneous soil cleansing is currently negligible. According to Gao and Zhu [9], the self-cleansing of a landfill surface contaminated with PAHs runs very slowly and is predominantly associated with the presence of autochthonic microorganisms with specific enzymatic activity. Applying the in situ bioremediation in a form of plant cultivation on polluted ground using particular organic-mineral additives [10-11] can enhance the contents of available forms of nutrients and improve water-air conditions, structure, and other functional properties of the soil.

The field experiments on soils poor in nutrients and contaminated with PAHs carried out by Olson et al. [12] revealed that the cultivation of perennial ryegrass in the 14-month cycle with the use of an entire set of pre-sowing and nursing treatments reduces up to $80 \%$ of PAH pollutants. They attribute a major role to loosening the soil by mechanical cultivation, and improved aeration promotes stimulation of native microflora. In addition, oxygen is incorporated into the hydrocarbon structure, and thus they become more susceptible to further transformation [13]. Under field conditions, the soil penetration by the root system improves the waterair relations, and root exudates are a nutrient for soil microorganisms [14].

Numerous pot experiments using plants have shown a beneficial effect of several percent additives of sewage sludge and bovine manure on the reduction of PAHs in contaminated soils as well as production of plant biomass [15-17]. After 60 days of incubation, the reduction of PAHs in pots with alfalfa Medicago sativa (L.) amounted to $25.8 \%$ versus $5.6 \%$ for the control [15]. The $2 \%$ addition of sludge into the PAH-contaminated soil affected the increased biomass of lettuce leaves Lactuca sativa (L.) and PAH bioaccumulation reduction by $60.3 \%$ as compared to the control, while a $10 \%$ addition reduced $\mathrm{PAH}$ content in the soil by $44 \%$ [16]. Studies performed on soil contaminated with anthracene and elevated salinity $7 \mathrm{dS} \cdot \mathrm{m}^{-1}$, the $60 \%$ reduction in contamination occurred due to a 112-day incubation period under aerobic conditions and municipal sewage sludge. It was found that sterilization of the sludge prior to its use eliminates the future effects to the control level [17]. The rate of changes depends on the intensity of applied treatments and the topsoil layer of the landfill gets the characteristics of soil in time.

The aim of our study was to determine the impact of selected organic additives and their dosages on the growth and development of selected plant species in the year of their application and in consequent experiments.

\section{Material and Methods}

\section{Field Study}

The three-factorial two-year field experiment was established on the ground of the landfill after ozokerite processing by means of sub-blocks (split-plot) in triplicate. The investigated factors were:

1. Type of additive: bovine manure (OB), subsoil after champignon cultivation (PP), sewage sludge from municipal treatment plant (OK), sawdust of deciduous trees $(\mathrm{T})$

2. Level of additive used: 4,8 , and $12 \% \mathrm{v} / \mathrm{v}$ (in relation to the volume of the $10 \mathrm{~cm}$ thickness topsoil layer) against control without any additive

3. Test plant species: white lupine - Lupinus albus (L.) var. Libid, Italian ryegrass - Lolium multiflorum var. Drohobycki-2, cocksfoot - Dactylis glomerata (L.) var. Drohobyczanka, and pink clover - Trifolium hybridum ver. Przedkarpacki-33

The study used relatively easily available and cheap organic additives. They were introduced before the experiment foundation in the first days of April 2013 onto the ground surface and manually dug. Supplemental fertilization was not applied, which allowed for assessment of the fertilization value of used additives. Experimental objects consisted of square-shape micro-plots of $2.25 \mathrm{~m}^{2}$, and the observations and measurements were performed in the central parts of their area of $1 \mathrm{~m}^{2}$.

Applied certified seeding material of a local origin met the quality standards of the $1^{\text {st }}$ class. The sowing amount was adopted in accordance with the agricultural recommendations and applied per hectare: $160 \mathrm{~kg}$ of white lupine, $15 \mathrm{~kg}$ of cocksfoot, $12 \mathrm{~kg}$ Italian ryegrass, and $6 \mathrm{~kg}$ of pink clover. The row sowing of all species seeds was carried out manually on 9 May 2013 and white lupine was sown on 15 April 2014.

In 2013 (preliminary experiment) and 2014 (consequent experiment), observations of growth and development were carried out during vegetation on a base of decimal BBCH scale [18]. Fresh weight of plants from particular objects was determined during the harvest.

The course of weather conditions was characterized according to the meteorological station in Drohobycz, about $10 \mathrm{~km}$ from the experimental site. 


\section{Laboratory Tests}

The ground samples were collected from a $0-10 \mathrm{~cm}$ layer of randomly selected surface of the landfill where the experiment was set. Samples were then subject to analyses for determining granulometric composition, $\mathrm{pH}$, salinity, and total carbon content, plus contents of available forms of phosphorus, potassium, and magnesium [19, 20], as well as $\mathrm{C}, \mathrm{H}, \mathrm{N}$, and $\mathrm{S}$ contents using a Vario EL Cube elemental analyzer. Samples of organic additives applied for phyto-remediation were subject to determinations of total forms of nitrogen, phosphorus, potassium, calcium, and magnesium by means of methods commonly used in chemical-agricultural laboratories [19]. Contents of chlorophyll A and B in fresh leaves of plants harvested in 2014 were determined on a base of optical density of pigments extract in $80 \%$ acetone involving the photometric technique at $\lambda=663$ and $\lambda=646 \mathrm{~nm}[21,22]$.

The topsoil layer of the experimental landfill revealed $10-15 \% \mathrm{v} / \mathrm{v}$ not decaying fine wooden fragments from the case of mining corridors, while mineral part contained $21 \%$ of sand fraction ( $\varnothing$ from 2.0 to $0.05 \mathrm{~mm}$ ), $65 \%$ of dust fraction ( $\varnothing$ from 0.05 to $0.002 \mathrm{~mm}$ ), and $14 \%$ of clay fraction $(\varnothing<0.002 \mathrm{~mm})$. In the $1-10 \mathrm{~cm}$ layer, reaction was alkaline ( $\mathrm{pH}$ about 7.8), moderate salinity of $3.2 \mathrm{dS} \cdot \mathrm{m}^{-1}$ (in water suspension 1:2.5), and determined content of total carbon $4.1 \%$. Carbon was present in different organic and mineral compounds - surely not belonging to the soil humus. Contents of available forms of potassium and magnesium were high and ranged to 340 and $195 \mathrm{mg} \mathrm{Mg} \cdot \mathrm{kg}^{-1}$, whereas that of phosphorus was low at $50 \mathrm{mg} \mathrm{P} \cdot \mathrm{kg}^{-1}$ of ground. Elemental analysis has shown $0.08 \% \mathrm{~N}, 3.67 \% \mathrm{C}, 0.916 \% \mathrm{H}$, and $0.050 \% \mathrm{~S}$.

The content of petroleum substances in the surface soil layer of the landfill was not a serious threat to the environment [1].

Organic additives used in the field experiment differed markedly with the content of basic nutrients (Table 1). Manure and sewage sludge were the most abundant in nitrogen, while subsoil after champignon cultivation included phosphorus and calcium. Sawdust from deciduous trees was the poorest in terms of nutritional value for plants. Compared with manure, it contained less nitrogen by $69.4 \%$, phosphorus by $98.7 \%$,

Table 1. Amounts of nutrients introduced with $4 \%\left(4 \mathrm{dm}^{3} \cdot \mathrm{m}^{-2}\right)$ of particular components.

\begin{tabular}{|c|c|c|c|c|c|c|}
\hline \multirow{2}{*}{ Organic additives } & $\mathrm{N}$ & $\mathrm{P}$ & $\mathrm{K}$ & $\mathrm{Ca}$ & $\mathrm{Mg}$ \\
\cline { 2 - 6 } & \multicolumn{5}{|c|}{$\mathrm{g} \cdot \mathrm{m}^{-2}$} \\
\hline Manure (OB) & 8.88 & 2.16 & 9.66 & 5.80 & 1.79 \\
\hline $\begin{array}{c}\text { Substrate after the } \\
\text { champignon cultivation } \\
\text { (PP) }\end{array}$ & 5.56 & 3.12 & 4.55 & 15.16 & 0.62 \\
\hline $\begin{array}{c}\text { Municipal sewage } \\
\text { sludge (OK) }\end{array}$ & 8.23 & 2.90 & 0.71 & 5.25 & 1.01 \\
\hline Sawdust (T) & 2.72 & 0.03 & 0.02 & 2.42 & 0.0 \\
\hline
\end{tabular}

potassium by $99.8 \%$, calcium by $38.3 \%$, and a total lack of magnesium.

The results were statistically processed using Statsoft software.

\section{Results and Discussion}

The analysis of weather from April to September (Figs 1 and 2) shows that in terms of the rainfall amount and the average 10-day temperatures, there were significant differences between years. More rainfall during this period was recorded in 2014 and they were particularly abundant in the second decade of May. Moreover, apart from a short period of drought in June, in the remaining months up to August, the rainfall sum was clearly higher than in 2013. However, in the growing season in 2013 there were more decades with a higher average temperature than in 2014.

The state of the surface layer of landfill soil contaminated with hydrocarbons did not allow for the emergence of any natural vegetation. Applied organic additives improved the soil enough to allow for the growth and development of plants on some experimental combinations (although their vegetation differed from growing on agricultural

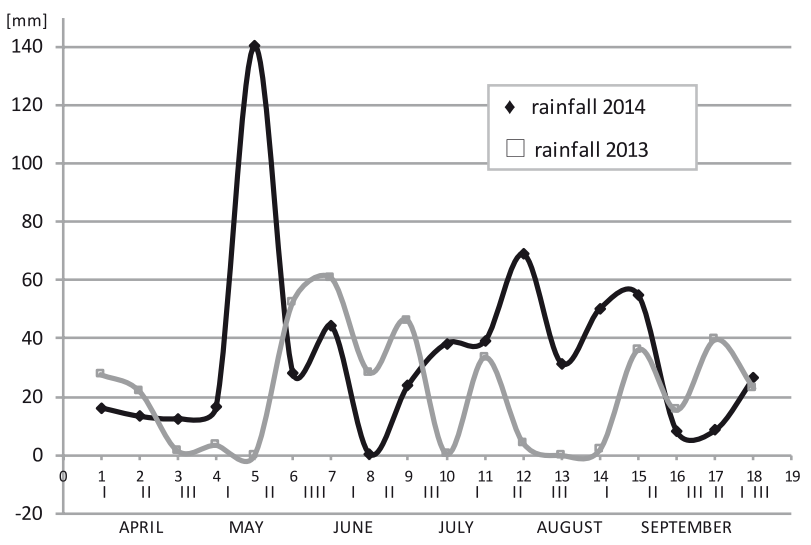

Fig. 1. Decade sums of rainfall during plant vegetation in 2013 and 2014 [mm].

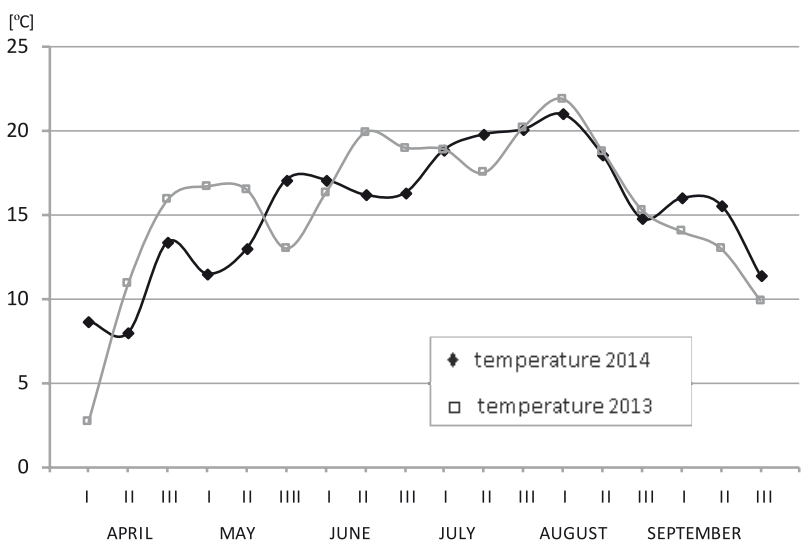

Fig. 2. Average decade air temperatures in April-September of 2013 and $2014\left[{ }^{\circ} \mathrm{C}\right]$. 
Table 2. The number of days from sowing to the second-leaf phase (A), and plant density (\%) at emergence phase in particular combinations (B).

\begin{tabular}{|c|c|c|c|c|c|c|c|c|c|}
\hline \multirow{3}{*}{ Plant species } & \multirow{3}{*}{$\begin{array}{c}\text { Dose } \\
\text { in } \% \mathrm{v} / \mathrm{v}\end{array}$} & \multicolumn{8}{|c|}{ Organic additive } \\
\hline & & \multicolumn{2}{|c|}{$\mathrm{OB}$} & \multicolumn{2}{|c|}{ PP } & \multicolumn{2}{|c|}{$\mathrm{OK}$} & \multicolumn{2}{|c|}{$\mathrm{T}$} \\
\hline & & A & $\mathrm{B}$ & A & $\mathrm{B}$ & A & $\mathrm{B}$ & A & B \\
\hline \multirow{6}{*}{$\begin{array}{l}\text { Lolium } \\
\text { multiflorum }\end{array}$} & 0 & 20 & 71 & 20 & 72 & 20 & 72 & 20 & 74 \\
\hline & 4 & 19 & 84 & 20 & 74 & 20 & 78 & 20 & 72 \\
\hline & 8 & 18 & 90 & 20 & 79 & 19 & 83 & 21 & 72 \\
\hline & 12 & 16 & 96 & 19 & 85 & 18 & 85 & 21 & 75 \\
\hline & \multicolumn{9}{|c|}{ A, LSD for: $\mathrm{a}-3, \mathrm{~b}-2, \mathrm{a} \times \mathrm{b}-3$} \\
\hline & \multicolumn{9}{|c|}{ B, LSD for: $\mathrm{a}-4, \mathrm{~b}-4, \mathrm{a} \times \mathrm{b}-6$} \\
\hline \multirow{6}{*}{$\begin{array}{l}\text { Dactylis } \\
\text { glomerata }\end{array}$} & 0 & 20 & 73 & 20 & 67 & 20 & 70 & 20 & 74 \\
\hline & 4 & 19 & 81 & 20 & 70 & 20 & 78 & 20 & 70 \\
\hline & 8 & 18 & 88 & 20 & 74 & 19 & 85 & 21 & 68 \\
\hline & 12 & 16 & 97 & 19 & 77 & 18 & 85 & 21 & 75 \\
\hline & \multicolumn{9}{|c|}{ A, LSD for: $\mathrm{a}-3, \mathrm{~b}-2, \mathrm{a} \times \mathrm{b}-3$} \\
\hline & \multicolumn{9}{|c|}{$\mathrm{B}, \mathrm{LSD}$ for: $\mathrm{a}-5, \mathrm{~b}-4, \mathrm{a} \times \mathrm{b}-5$} \\
\hline \multirow{6}{*}{$\begin{array}{l}\text { Trifolium } \\
\text { hybridum }\end{array}$} & 0 & 18 & 70 & 18 & 68 & 18 & 75 & 18 & 72 \\
\hline & 4 & 15 & 78 & 17 & 74 & 17 & 80 & 18 & 68 \\
\hline & 8 & 14 & 91 & 17 & 72 & 15 & 78 & 19 & 65 \\
\hline & 12 & 12 & 95 & 16 & 75 & 14 & 83 & 19 & 66 \\
\hline & \multicolumn{9}{|c|}{ A, LSD for: $a-3, b-3, a \times b-4$} \\
\hline & \multicolumn{9}{|c|}{ B, LSD for: $\mathrm{a}-6, \mathrm{~b}-4, \mathrm{a} \times \mathrm{b}-5$} \\
\hline \multirow{4}{*}{$\begin{array}{l}\text { Lupinus } \\
\text { albus } *\end{array}$} & 0 & 18 & 92 & 17 & 94 & 18 & 95 & 18 & 93 \\
\hline & 4 & 14 & 95 & 17 & 94 & 16 & 93 & 18 & 92 \\
\hline & 8 & 13 & 97 & 17 & 96 & 15 & 95 & 17 & 90 \\
\hline & 12 & 11 & 97 & 16 & 95 & 15 & 95 & 17 & 88 \\
\hline \multirow{6}{*}{$\begin{array}{l}\text { Lupinus } \\
\text { albus ** }\end{array}$} & 0 & 20 & 90 & 20 & 91 & 21 & 91 & 21 & 90 \\
\hline & 4 & 18 & 94 & 19 & 95 & 19 & 94 & 20 & 91 \\
\hline & 8 & 18 & 93 & 19 & 96 & 18 & 93 & 19 & 92 \\
\hline & 12 & 17 & 95 & 18 & 97 & 18 & 95 & 19 & 91 \\
\hline & \multicolumn{9}{|c|}{$\begin{array}{l}\text { A, LSD for: } \mathrm{C}-\text { n.s., } \mathrm{a}-3, \mathrm{~b}-2 \\
- \text { n.s., } \mathrm{C} \times \mathrm{b}-\text { n.s., } \mathrm{a} \times \mathrm{b}-2, \mathrm{C} \times \mathrm{a} \times \mathrm{b}-\text { n.s. }\end{array}$} \\
\hline & \multicolumn{9}{|c|}{$\begin{array}{c}\text { B, LSD for: } \mathrm{C}-\text { n.s., } \mathrm{a}-4, \mathrm{~b}-\text { n.s., } \\
\mathrm{C} \times \mathrm{a}-5, \mathrm{C} \times \mathrm{b}-5, \mathrm{a} \times \mathrm{b}-6, \mathrm{C} \times \mathrm{a} \times \mathrm{b}-\text { n.s. }\end{array}$} \\
\hline
\end{tabular}

soils). In the preliminary experiment on objects containing manure, young plants showed more intensive growth, and in the second leaf phase Italian ryegrass and cocksfoot reached about 1-4 days earlier as compared to the control (Table 2), clover by 3-6 days, and white lupine by 4-7 days (in the second year, white lupine reached this phase about 2-3 days sooner). Increased rate of seedlings growth was always associated with higher doses of introduced manure. The addition of the substrate after champignon cultivation and municipal sewage sludge, like the addition of manure, accelerated plant growth, but to a lesser extent, by 1-3 days as compared to the control. In contrast, the latest twoleaves phase was reached by plants in the control object and after using the sawdust, the dose of which had no apparent effect on their growth.
The harmful (toxic) impact of PAHs in landfill soil on young plants revealed in the form of fading and leaf discoloration, which led in consequence to dying seedlings. Loss of young plants depended on the type of introduced additives and its dose as well as the plant species (Table 2). The strongest positive reaction of the plant population size, proportional to the introduced dose, was recorded on objects with the addition of manure, municipal sludge, and subsoil after champignon cultivation acted less, while the addition of sawdust was neutral and even caused a few percentage points regression of clover and lupine sown in 2013.

Emergence of the test plant species after the use of additives varied. White lupine with the highest weight of a single kernel at this stage best tolerated the adverse 
Table 3. Influence of particular components and their doses on the development of Italian ryegrass.

\begin{tabular}{|c|c|c|c|c|c|c|c|c|c|c|c|c|c|c|c|c|c|c|c|}
\hline \multirow{3}{*}{ Year } & \multirow{3}{*}{ Growth phases code } & \multicolumn{17}{|c|}{$\begin{array}{l}\text { The number of days from sowing (beginning vegetation in the second year of cultivation) } \\
\text { to achieve a given phase }\end{array}$} & \multirow{3}{*}{ Average } \\
\hline & & \multirow{2}{*}{ K } & \multicolumn{4}{|c|}{ OB } & \multicolumn{4}{|c|}{ PP } & \multicolumn{4}{|c|}{ OK } & \multicolumn{4}{|c|}{$\mathrm{T}$} & \\
\hline & & & 4 & 8 & 12 & Śr. & 4 & 8 & 12 & Śr. & 4 & 8 & 12 & Śr. & 4 & 8 & 12 & Śr. & \\
\hline \multirow{9}{*}{2013} & [phase 21] & 28 & 25 & 23 & 20 & 23 & 28 & 27 & 27 & 27 & 27 & 25 & 24 & 25 & 29 & 28 & 28 & 28 & 26 \\
\hline & \multicolumn{19}{|c|}{ LSD for: $a-$ n.s., $b-$ n.s., $a x b-6$} \\
\hline & \multicolumn{19}{|c|}{ I cut - harvested in 46 day after sowing } \\
\hline & [phase 37] & 71 & 68 & 63 & 60 & 64 & 70 & 66 & 65 & 67 & 66 & 64 & 63 & 64 & 71 & 74 & 76 & 74 & \\
\hline & [phase 51] & 81 & 79 & 78 & 75 & 77 & 81 & 80 & 80 & 80 & 79 & 78 & 76 & 78 & 81 & 82 & 85 & 83 & 80 \\
\hline & \multicolumn{19}{|c|}{ LSD for: $\mathrm{a}-$ n.s., $\mathrm{b}-$ n.s., $\mathrm{axb}-5$} \\
\hline & \multicolumn{19}{|c|}{ II cut- harvested in 85 day after sowing } \\
\hline & $\begin{array}{l}\text { The end of the } \\
\text { growing season }\end{array}$ & 101 & 106 & 112 & 120 & 113 & 105 & 108 & 116 & 110 & 106 & 109 & 114 & 110 & 96 & 92 & 83 & 90 & 105 \\
\hline & \multicolumn{19}{|c|}{ LSD for: $a-7, b-6, a x b-8$} \\
\hline \multirow{10}{*}{2014} & [phase 37] & 40 & 37 & 37 & 33 & 36 & 39 & 37 & 37 & 38 & 40 & 39 & 36 & 38 & $*$ & $*$ & * & $*$ & \\
\hline & [phase 51] & 58 & 56 & 51 & 44 & 50 & 56 & 55 & 53 & 55 & 57 & 53 & 50 & 53 & & & & & 54 \\
\hline & \multicolumn{19}{|c|}{ LSD for: $a-5, b-5, a x b-7$} \\
\hline & \multicolumn{19}{|c|}{ I cut - harvested in 79 day from the beginning of vegetation } \\
\hline & [phase 37] & 90 & 98 & 97 & 91 & 95 & 94 & 98 & 100 & 97 & 97 & 96 & 93 & 95 & & & & & \\
\hline & [phase 51] & 95 & 100 & 109 & 112 & 107 & 99 & 110 & 115 & 111 & 104 & 110 & 115 & 110 & & & & & 106 \\
\hline & \multicolumn{19}{|c|}{ LSD for: $a-6, b-5, a x b-7$} \\
\hline & \multicolumn{18}{|c|}{ II cut - harvested in 118 day from the beginning of vegetation } & \\
\hline & $\begin{array}{l}\text { The end of the } \\
\text { growing season }\end{array}$ & 165 & 177 & 189 & 200 & 189 & 170 & 172 & 175 & 172 & 170 & 175 & 181 & 175 & & & & & 175 \\
\hline & & & & & & LSD & for: & -13 & $b-1$ & 1 , a & -16 & & & & & & & & \\
\hline
\end{tabular}

conditions. Plant density above $90 \%$ in the control object under the influence of additives was increased to $94-96 \%$. At fine-seed cultures (ryegrass, cocksfoot, and clover) on the control object from 67 to $75 \%$ of plants entered the second-leaf phase, and the addition of municipal sludge and subsoil after champignon cultivation increased the density population to $75-85 \%$.

The course of further growth and development of plants grown in the landfill soil containing PAHs is shown in Tables 3-6. Plant vegetation in the year of organic additives application depended to some extent on the improvement in environmental conditions, in particular the abundance of nutrients and weather conditions. In addition, the accumulation of PAHs by plants over a long period of time impairs their water management as well as respiration and transport of components through the cell membranes, which affects plant conditions [23]. Plant uniformity within particular plots during the tillering stage, the development of rosettes, and stem elongation was poor; many of them inhibited their growth and then faded, while the others did not reach the standard size. In the case of perennial crops, it made more favorable conditions at the same time masking the losses. The vegetation of young perennial ryegrass plants did not depend clearly on the type and dose of organic additives used (Table 3). Acceleration of heading [phase 21] was stimulated only by higher doses of manure, proportionally to the dose, by eight days at the $12 \%$ dose. After the aboveground plant mass harvest (I cut) carried out at a single date, 46 days after sowing, further plant growth and development proceeded regardless of the type and dose of additives until the earing phase [phase 51]. There was, however, heading acceleration on objects with $12 \%$ addition of bovine manure and sewage sludge as compared to the control, by six and five days, respectively. The substrate after mushroom harvesting did not affect the vegetation rate during this phase, and the addition of sawdust delayed the heading of perennial ryegrass. Such distribution indicates the level of a plant's nutrition associated with the chemical composition of applied organic additives and the rate of nutrients released into the ground. Clear differences within the end of the perennial ryegrass growing season referred to the type and dose of organic additives. Bovine manure, municipal sludge, and the substrate after the mushroom harvest lengthened the growing season, respectively, to 113 , 110 , and 110 days against 101 days for the control, while sawdust shortened the perennial ryegrass growing season to 80 days. 
Table 4. Influence of organic additives and their doses on the development of cocksfoot.

\begin{tabular}{|c|c|c|c|c|c|c|c|c|c|c|c|c|c|c|c|c|c|c|c|}
\hline \multirow{3}{*}{ Year } & \multirow{3}{*}{$\begin{array}{c}\text { Growth phases } \\
\text { code }\end{array}$} & \multicolumn{17}{|c|}{$\begin{array}{l}\text { The number of days from sowing (beginning vegetation in the second year of cultivation) } \\
\text { to achieve a given phase }\end{array}$} & \multirow{3}{*}{ Average } \\
\hline & & \multirow{2}{*}{$\mathrm{K}$} & \multicolumn{4}{|c|}{ OB } & \multicolumn{4}{|c|}{ PP } & \multicolumn{4}{|c|}{ OK } & \multicolumn{4}{|c|}{$\mathrm{T}$} & \\
\hline & & & 4 & 8 & 12 & Avg. & 4 & 8 & 12 & Avg. & 4 & 8 & 12 & Avg. & 4 & 8 & 12 & Avg. & \\
\hline \multirow{6}{*}{2013} & [phase 21] & 30 & 26 & 25 & 23 & 25 & 30 & 30 & 32 & 31 & 30 & 29 & 29 & 29 & 30 & 30 & 31 & 30 & 29 \\
\hline & \multicolumn{19}{|c|}{ LSD for: $a-$ n.s., $b-$ n.s., $a x b-6$} \\
\hline & \multicolumn{18}{|c|}{ I cut- harvested in 46 day after sowing } & \\
\hline & \multicolumn{18}{|c|}{ II cut- harvested in 85 day after sowing } & \\
\hline & $\begin{array}{l}\text { The end of } \\
\text { growing season }\end{array}$ & 90 & 94 & 98 & 100 & 97 & 93 & 96 & 97 & 95 & 92 & 94 & 98 & 95 & 88 & 84 & 82 & 85 & 92 \\
\hline & \multicolumn{19}{|c|}{ LSD for: $\mathrm{a}-5, \mathrm{~b}-$ n.s., $\mathrm{axb}-7$} \\
\hline \multirow{10}{*}{2014} & [phase 37] & 50 & 48 & 45 & 41 & 45 & 50 & 48 & 47 & 48 & 49 & 47 & 46 & 47 & * & $*$ & * & $*$ & \\
\hline & [phase 51] & 70 & 65 & 63 & 59 & 62 & 68 & 65 & 61 & 65 & 67 & 65 & 64 & 65 & & & & & 65 \\
\hline & \multicolumn{19}{|c|}{ LSD for: $a-5, b-4, a x b-6$} \\
\hline & \multicolumn{18}{|c|}{ I cut - harvested in 79 day from the beginning of vegetation } & \\
\hline & phase 37] & 100 & 97 & 95 & 90 & 94 & 98 & 98 & 97 & 98 & 100 & 101 & 100 & 100 & & & & & \\
\hline & [phase 51] & 115 & 115 & 112 & 112 & 113 & 115 & 114 & 115 & 115 & 115 & 115 & 115 & 115 & & & & & 114 \\
\hline & \multicolumn{19}{|c|}{ LSD for: $\mathrm{a}-$ n.s., $\mathrm{b}-$ n.s., $\mathrm{axb}-$ n.s. } \\
\hline & \multicolumn{18}{|c|}{ II cut - harvested in 118 day from the beginning of vegetation } & \\
\hline & $\begin{array}{l}\text { The end of } \\
\text { growing season }\end{array}$ & 200 & 205 & 209 & 218 & 211 & 202 & 204 & 208 & 205 & 202 & 204 & 208 & 205 & & & & & 205 \\
\hline & \multicolumn{19}{|c|}{ LSD for: $a-11, b-8, a x b-13$} \\
\hline
\end{tabular}

* - lack of plants

LSD for: $a$ - type of additive, $b$ - dose of additive, n.s. - non-significant

In the subsequent experiment, in a year with unfavorable distribution of rainfall, the type and dose of organic additives clearly influenced the course of perennial ryegrass growth, referring to the weather conditions (Table 3). Acceleration of spring (before the first cut) plant heading [phase 51] occurring in the second half of May (at optimal soil moisture conditions) was observed on objects, where municipal sludge and manure were used, respectively, by eight and five days relative to the control. The use of the substrate after the mushroom harvest did not give significant results, while plants did not resume the spring vegetation on objects with sawdust. Doses of additives at $8 \%$ and $12 \%$ levels influenced the acceleration of ryegrass spring heading, respectively, by five and nine days as compared to the control, whereas a dose of $4 \%$ additives had an insignificant impact.

The summer ryegrass heading (before the second cut) was observed in the second half of June, when there was a soil and atmospheric drought. The dry period and high temperatures have lasted since significant rainfall in the first decade of May until mid-July, which determined the insufficient supply of plants in water and nutrients. The organic additives delayed the heading of plants relative to the control from 12 days on manure-treated objects to 16 days with the addition of substrate after the mushroom harvest. Levels of additives also delayed the plant's heading from six days at a $4 \%$ dose up to 19 days at a dose of $12 \%$ relative to the control. Further plant vegetation, until the first half of September, took place under more favorable weather conditions. The ryegrass plants ended vegetation the earliest on the control object, after 165 days of vegetation, and the use of manure prolonged plant growth to 189 days. Higher doses ( $8 \%$ and $12 \%$ ) of additives significantly prolonged the ryegrass vegetation by 14 and 20 days as compared to the control.

Young plants of another grass species involved in the experiment, cocksfoot, entered the tillering phase [phase 21] about 29 days after sowing (Table 4) and 10 days after the second leaf stage [phase 12]. A significant acceleration in propagation under the influence of experimental factors occurred only on objects with $12 \%$ addition of manure by seven days as compared to the control. For harvesting vegetative plant mass, the first cut was made 46 days after sowing, while the second was 85 days after sowing. The yield of the second cut contained a few generative shoots. The habitat conditions caused further summer growth of plants to be heavily restricted and soon they have completed their vegetation. It lasted an average of 92 days from the sowing date and depended on the type of additive used. The length of a plant's vegetation period on the control 
Table 5. Influence of organic additives and their doses on the development of pink clover.

\begin{tabular}{|c|c|c|c|c|c|c|c|c|c|c|c|c|c|c|c|c|c|c|c|}
\hline \multirow{3}{*}{ Year } & \multirow{3}{*}{$\begin{array}{c}\text { Growth } \\
\text { phases code }\end{array}$} & \multicolumn{17}{|c|}{$\begin{array}{l}\text { The number of days from sowing (beginning vegetation in the second year of cultivation) to achieve } \\
\text { a given phase }\end{array}$} & \multirow{3}{*}{ Average } \\
\hline & & \multirow{2}{*}{$\mathrm{K}$} & \multicolumn{4}{|c|}{ OB } & \multicolumn{4}{|c|}{ PP } & \multicolumn{4}{|c|}{$\mathrm{OK}$} & \multicolumn{4}{|c|}{$\mathrm{T}$} & \\
\hline & & & 4 & 8 & 12 & Avg. & 4 & 8 & 12 & Avg & 4 & 8 & 12 & Avg. & 4 & 8 & 12 & Avg. & \\
\hline \multirow{12}{*}{2013} & [phase 30] & 46 & 43 & 39 & 37 & 40 & 46 & 44 & 44 & 45 & 45 & 43 & 42 & 43 & 46 & 47 & 47 & 47 & 44 \\
\hline & \multicolumn{19}{|c|}{ LSD for: $\mathrm{a}-5, \mathrm{~b}-$ n.s., $\mathrm{axb}-7$} \\
\hline & [phase 55] & 62 & 58 & 54 & 48 & 53 & 59 & 56 & 55 & 57 & 59 & 57 & 53 & 56 & 56 & 52 & 49 & 52 & 56 \\
\hline & \multicolumn{19}{|c|}{ LSD for: $a-5, b-5, a x b-8$} \\
\hline & \multicolumn{18}{|c|}{ I cut- harvested in 62 day after sowing } & \\
\hline & [phase 55] & 77 & 73 & 69 & 67 & 70 & 73 & 70 & 64 & 69 & 72 & 71 & 68 & 70 & 75 & 75 & 74 & 75 & 72 \\
\hline & \multicolumn{19}{|c|}{ LSD for: $a-4, b-5, a x b-7$} \\
\hline & [phase 65] & 92 & 89 & 88 & 85 & 87 & 89 & 85 & 82 & 85 & 90 & 86 & 80 & 85 & 91 & 90 & 87 & 89 & \\
\hline & [phase 89] & 108 & 106 & 105 & 103 & 105 & 106 & 102 & 100 & 103 & 105 & 103 & 102 & 103 & 107 & 105 & 104 & 105 & \\
\hline & \multicolumn{18}{|c|}{ II cut- harvested in 109 day after sowing } & \\
\hline & $\begin{array}{c}\text { The end of } \\
\text { growing } \\
\text { season }\end{array}$ & 124 & 130 & 136 & 140 & 135 & 127 & 125 & 133 & 130 & 127 & 130 & 132 & 130 & 122 & 119 & 119 & 120 & 128 \\
\hline & \multicolumn{19}{|c|}{ LSD for: $a-6, b-6, a x b-9$} \\
\hline \multirow{12}{*}{2014} & [phase 30] & 26 & 26 & 27 & 25 & 26 & 25 & 26 & 26 & 26 & 26 & 27 & 26 & 26 & $*$ & $*$ & $*$ & $*$ & \\
\hline & [phase 55] & 65 & 65 & 65 & 68 & 66 & 63 & 60 & 58 & 60 & 64 & 64 & 66 & 65 & & & & & 64 \\
\hline & \multicolumn{19}{|c|}{ LSD for: $\mathrm{a}-$ n.s., $\mathrm{b}-$ n.s., $\mathrm{axb}-7$} \\
\hline & \multicolumn{18}{|c|}{ - I cut harvested in 70 day from the beginning of vegetation } & \\
\hline & [phase 55] & 73 & 75 & 76 & 79 & 77 & 74 & 73 & 73 & 73 & 73 & 76 & 77 & 75 & & & & & 74 \\
\hline & \multicolumn{19}{|c|}{ LSD for: $\mathrm{a}-\mathrm{n} . \mathrm{s}, \mathrm{b}-\mathrm{n} . \mathrm{s}, \mathrm{axb}-\mathrm{n} . \mathrm{s}$} \\
\hline & [phase 65] & 85 & 88 & 91 & 92 & 90 & 85 & 86 & 88 & 87 & 87 & 89 & 93 & 90 & & & & & \\
\hline & [phase 89] & 103 & 107 & 111 & 111 & 110 & 104 & 10 & 108 & 105 & 106 & 107 & 110 & 108 & & & & & 108 \\
\hline & \multicolumn{19}{|c|}{ LSD for: $a-6, b-7, a x b-$ n.s. } \\
\hline & \multicolumn{18}{|c|}{ - II cut harvested in 111 day from the beginning of vegetation } & \\
\hline & $\begin{array}{l}\text { The end of } \\
\text { growing } \\
\text { season }\end{array}$ & 151 & 166 & 178 & 181 & 175 & 159 & 162 & 171 & 164 & 163 & 172 & 176 & 170 & & & & & 165 \\
\hline & \multicolumn{19}{|c|}{ D for: $a-6, b-7, a x b-11$} \\
\hline
\end{tabular}

* - lack of plants $\quad$ LSD for: $\mathrm{a}$ - type of additive, $\mathrm{b}$ - dose of additive, n.s. - non-significant

object was 90 days and the addition of sawdust shortened this time by five days, while manure, substrate after the champignons harvest, and municipal sludge prolonged it by seven, five, and five days, respectively. On objects with manure, $8 \%$ and $12 \%$ doses had a positive impact on extending the growing season, municipal sludge, and substrate after the mushroom harvest at a $12 \%$ dose, while objects with sawdust addition revealed a negative effect of the $12 \%$ addition, which shortened plant growth by eight days.

In the second year of the experiment, the cocksfoot plants on objects with the addition of sawdust did not resume vegetation, whereas the other ones entered the spring phase of heading (before the first cut) about 65 days after the beginning of vegetation; the earliest on objects with manure addition after 62 days as compared to the control, where heading occurred after 70 days of vegetation. Larger quantities of additives ( $8 \%$ and $12 \%)$ significantly accelerated heading of cocksfoot plants by six and nine days, respectively. The addition of manure had particularly positive effects on heading acceleration: $12 \%$ by 11 days, and $8 \%$ by seven days. Further plant vegetation after harvest of the first cut occurred during the soil dry period, which affected the status of plants. 
However, cocksfoot belonging to the tufted grass producing a very dense root system, and bore the adverse conditions relatively well without showing a clearer response to the experimental factors. Summer heading was observed after 114 days of vegetation, and harvest of the aboveground parts of plants was performed a few days later (July 11). Favorable weather conditions in the second half of summer and early autumn allowed for a long vegetation of cocksfoot plants until the first days of October. Plants on the control object ended their vegetation the earliest after 200 days. Among the organic additives used, only manure prolonged plant growth by 11 days. Doses of $4 \%$ and $8 \%$ of the additives had no impact on the length of the cocksfoot plants growing season. Particularly noticeable was the impact of manure on extending the growing season as observed on objects with the addition of $12 \%-$ at 18 days as compared to the control.

Under experimental conditions, the young plants of pink clover after producing (44 days after sowing, on average) about 4-6 true leaves per rosette (Table 5), entered the phase of stem elongation [phase 30]. Only a positive action of manure to this phase acceleration was recorded. Generally, the doses of additives did not affect the plant growth rate at this stage, but in the case of manure application at doses of $8 \%$ and $12 \%$ of additive, they accelerated the start of stem elongation phase, respectively by seven and nine days as compared to the control. The first single flowers in the heads of clover [phase 55] appeared 56 days after sowing. Applied additives accelerated this phase: by five days for substrate after champignon harvest, to 10 days for sawdust (in reference to control). Higher doses of additives accelerated the appearance of the flowers in clover heads, as compared to the control, in proportion to the applied doses. After quite a late harvest of the first cut, plants were relatively quickly regrown and after 16 days they re-entered into the phase of flower appearance in the heads [phase 55]. With the exception of sawdust, the remaining additives that period had a beneficial effect on plant growth. Acceleration of this phase (from four to nine days as compared to the control) occurred also under the influence of increasing doses (4 to 12\%). On objects with the addition of municipal sludge, significant acceleration of this phase occurred at a $12 \%$ dose, while the manure and substrate after mushroom harvest were effective at $8 \%$ and $12 \%$ doses. After harvesting the second cut, conditions allowed for a further 2-3 week vegetation of clover plants, which ended the earliest on objects with the addition of sawdust and control after 120 and 124 days, respectively, while the latest was on an object with manure after 135 days. The dose amount also affected the duration of the clover vegetation period, which was the longest on objects with $12 \%$ dose of additives by seven days as compared to the control. Prolonging the clover growing season was associated with interaction of the type with doses of additives. The most beneficial results were recorded for manure at $8 \%$ and $12 \%$ doses, which prolonged plant vegetation, respectively, to 136 and 140 days, as well as substrate after champignon to 133 days against 124 days for the control.

In the second year of research, tested clover plants on objects with the addition of sawdust did not resume spring vegetation. On other subsequent experimental objects, the first flowers in clover inflorescences [phase 55] appeared about May 18, or 64 days since the rise of spring vegetation, regardless of the research factors. Significant acceleration of this phase by seven days, as a result of interaction, was found on objects with $12 \%$ addition of the substrate after the champignon harvest. After harvesting the first cut, further vegetation of test plants proceeded similarly and fairly quickly till the appearance of the first

Table 6. Influence of particular components and their doses on the development of white lupine.

\begin{tabular}{|c|c|c|c|c|c|c|c|c|c|c|c|c|c|c|c|c|c|c|c|}
\hline \multirow{3}{*}{ Year } & \multirow{3}{*}{$\begin{array}{c}\text { Growth } \\
\text { phases code }\end{array}$} & \multicolumn{17}{|c|}{ The number of days from sowing to achieve given phase } & \multirow{3}{*}{ Average } \\
\hline & & \multirow{2}{*}{$\mathrm{K}$} & \multicolumn{4}{|c|}{ OB } & \multicolumn{4}{|c|}{$\mathrm{PP}$} & \multicolumn{4}{|c|}{$\mathrm{OK}$} & \multicolumn{4}{|c|}{$\mathrm{T}$} & \\
\hline & & & 4 & 8 & 12 & Avg. & 4 & 8 & 12 & Avg. & 4 & 8 & 12 & Avg. & 4 & 8 & 12 & Avg. & \\
\hline \multirow{5}{*}{2013} & [phase 31] & 32 & 30 & 26 & 25 & 27 & 30 & 30 & 29 & 30 & 31 & 30 & 30 & 30 & 32 & 32 & 34 & 33 & 30 \\
\hline & [phase 53] & 52 & 49 & 45 & 45 & 46 & 52 & 49 & 48 & 50 & 51 & 49 & 45 & 48 & 53 & 53 & 55 & 54 & 50 \\
\hline & [phase 63] & 63 & 63 & 61 & 60 & 62 & 62 & 60 & 61 & 60 & 62 & 60 & 60 & 61 & 63 & 64 & 64 & 64 & 62 \\
\hline & [phase 83] & 73 & 74 & 78 & 79 & 77 & 73 & 74 & 74 & 74 & 73 & 74 & 73 & 73 & 73 & 74 & 73 & 73 & 74 \\
\hline & \multicolumn{19}{|c|}{ - harvested 80 days after sowing } \\
\hline \multirow{5}{*}{2014} & [phase 31] & 32 & 31 & 30 & 30 & 30 & 32 & 31 & 31 & 31 & 32 & 31 & 28 & 30 & 32 & 31 & 29 & 31 & 31 \\
\hline & [phase 53] & 54 & 54 & 52 & 49 & 52 & 53 & 52 & 52 & 52 & 54 & 52 & 51 & 52 & 54 & 54 & 55 & 54 & 53 \\
\hline & [phase 63] & 70 & 68 & 67 & 64 & 66 & 69 & 69 & 70 & 69 & 68 & 66 & 66 & 67 & 69 & 70 & 72 & 70 & 68 \\
\hline & [phase 83] & 72 & 76 & 81 & 81 & 79 & 73 & 76 & 77 & 75 & 73 & 75 & 76 & 75 & 72 & 72 & 71 & 72 & 75 \\
\hline & \multicolumn{19}{|c|}{ - harvested 81 days after sowing } \\
\hline
\end{tabular}

LSD for: $\mathrm{C}$ - year of research, a - type of additive, $\mathrm{b}$ - dose of additive, n.s. - non significant 
flowers in inflorescences (in late May-June). The period of the June drought adversely affected the condition of plants, their development, and uniformity. The July rain improved the conditions of plants that reached their full maturity associated with pods browning [phase 89] after about 108 days of vegetation, on average. Among the organic additives, only manure significantly delayed this phase by seven days in comparison to the control. The dose of additives was less affected by the date of pod maturity, when a $12 \%$ dose acted around the significance limit. After harvest of the second experimental cut, clover vegetation still took place. De-colorization and drying of plant leaves on particular experimental objects was clearly differentiated and on average they ended their vegetation after 165 days. The use of additives on the soil surface (mostly manure) definitely prolonged clover plant growth by about 24 days and sewage sludge by 19 days, and less the substrate after harvesting of mushrooms by 13 days as compared to the control. Also, doses of additives significantly affected the growing completion date in proportion to their size. Plant vegetation was prolonged respectively by 12,20 , and 25 days as compared to the control, which was 151 days, along with the increase of the dose.

\section{Total chlorophyll A+B}
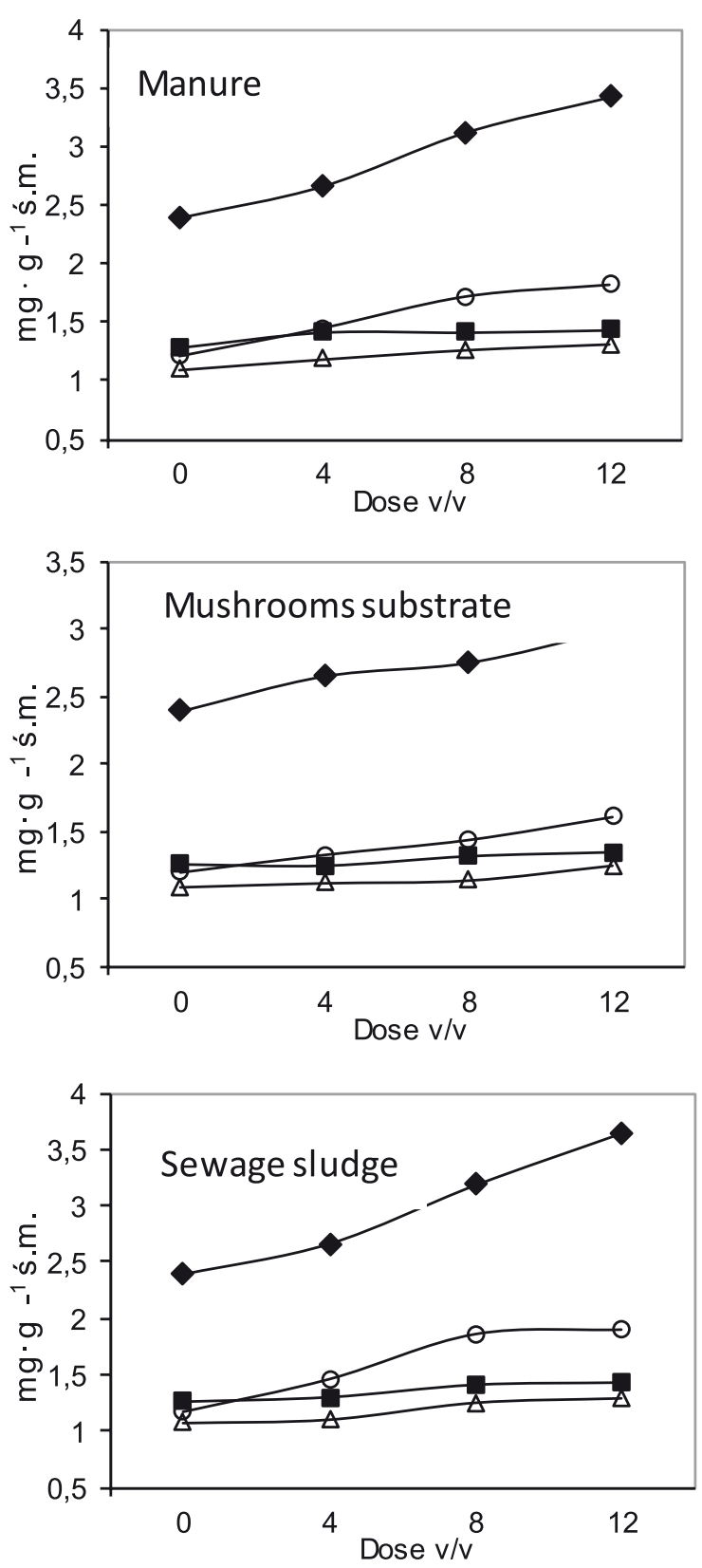

\section{Ratio of chlorophyll A/B}
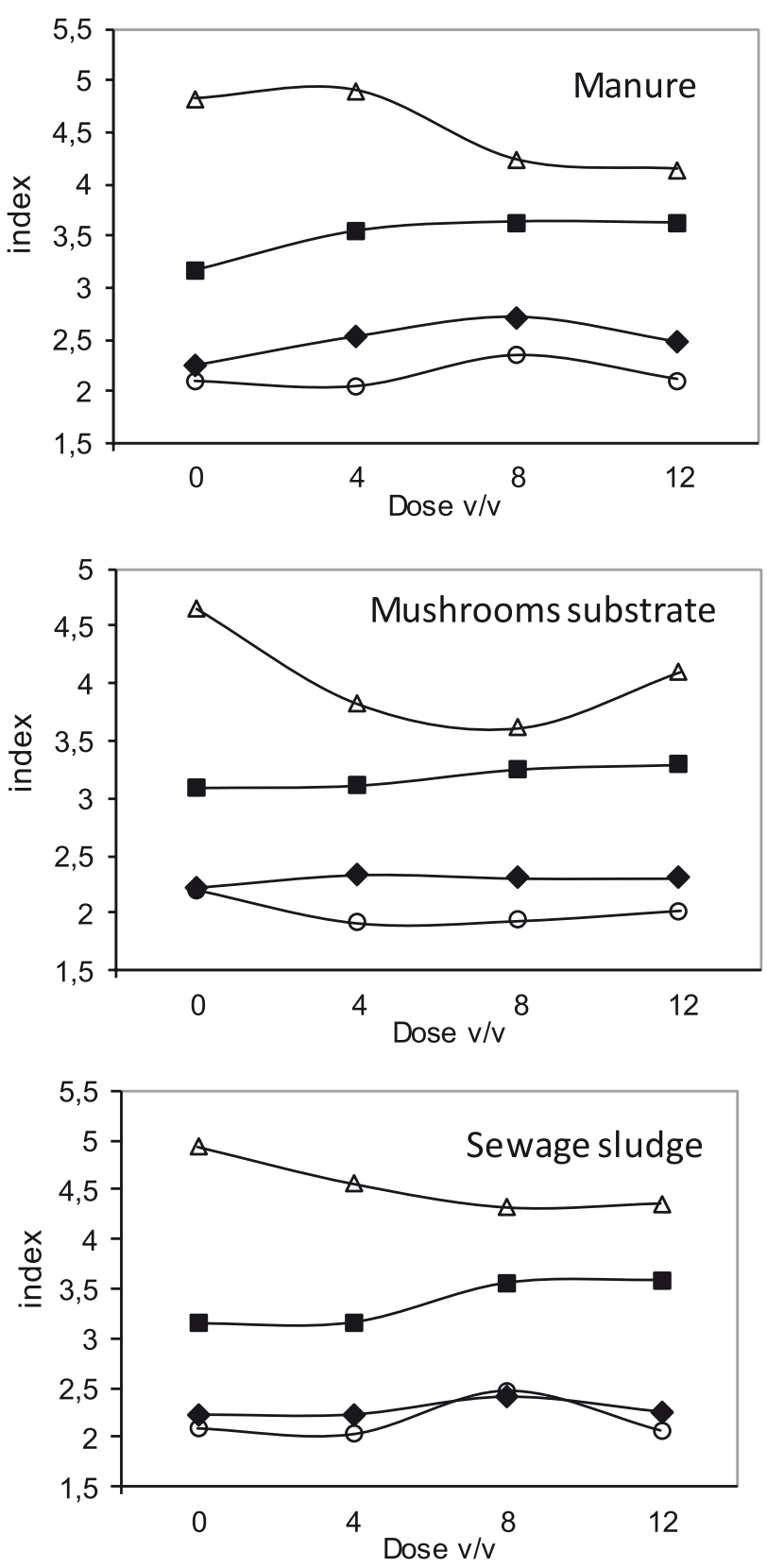

\section{- - Lupinus albus $\rightarrow$-Lolium multiflorum}

\section{$\triangle-$ Dactylis glomerata}

Fig. 3. Influence of particular components and their dose on content of chlorophyll $(A+B)$ and $A / B$ ratio in grown plants. 
The white lupine plants (annual species) from the leaf rosette formation phase, which involves intensive uptake of components from the substrate, showed the highest sensitivity among the test plants toward soil pollution with hydrocarbons. It was manifested in both years of research as a substantial reduction of growth, rapid rate of plant development, and seed maturation, at the absence of reaction to the type and dose of additives (Table 6). Stem elongation [phase 31], when plants produced 4-6 leaves per rosette, occurred from 25 to 34 days after sowing, regardless of the sowing date (09.05.2013 and 15.04.2014). The first flower buds at the top of very poorly developed main shoots [phase 53] appeared after 45-55 days of vegetation. White lupine flowering [phase 63] during the study years was more differentiated, which should be attributed to the sowing date. In the subsequent experiment, keeping the optimum sowing date and in very humid May, lupine plants reached the full flowering stage in the third decade of June, about 69 days after sowing, while later sowing (by about 3 weeks) in a preliminary experiment, shifted the flowering to the turn of the first and second decade of July. However, it shortened the period from sowing until flowering to about 62 days. Pod browning [phase 83] associated with wax maturity of plant seeds was observed 71-81 days after sowing, which did not depend on the experimental factors.

In objects with white lupine, around $30 \%$ of the plants remained by the wax maturity phase, and they were sparsely branched, with 1-2 pods and 1-2 seeds developed. Lupine plants prematurely dried up after about 70-80 days of vegetation (Table 6), while under agricultural cultivation their growing period reached 120-140 days [24]. The sensitivity of lupine results from its root system construction, which is a pile type with a small number of short side branches.

The rate of crop growth as a function of photosynthesis intensity depended, among others, on the content of photosynthetic pigments in leaves - in particular chlorophyll A and B. The results of chlorophyll A and B contents determination in leaves of the second cut during the consequent experiment are shown in diagrams (Fig. 3) as their sum and $\mathrm{A} / \mathrm{B}$ ratio. The content of chlorophyll $\mathrm{A}$ and $\mathrm{B}$, as a genetic trait, was strongly modified not by the type, but the dose of applied organic components. The use of a $12 \%$ addition of municipal sewage sludge into the subsoil increased the chlorophyll A and B sum in plants by $40 \%$, manure by $35 \%$, and subsoil after champignon cultivation by $22 \%$ in relation to the control object, where this parameter amounted to $1.47-1.49 \mathrm{mg} \cdot \mathrm{g}^{-1}$ (Fig. 3). Contents of chlorophyll A and B sum in leaves of grasses and white lupine were similar in control objects $\left(1.06-1.28 \mathrm{mg} \cdot \mathrm{g}^{-1}\right)$, while in leaves of clover it was twice as high. Organic additives contributed to the increase of the sum by $11 \%$ in ryegrass, by $18 \%$ in lupine, and by $39 \%$ in clover leaves.

Plant response to the dose of additives, measured as a chlorophyll content, is related to the level of available nitrogen in the landfill soil in the second year of the application. Italian ryegrass, under experimental conditions, responded less to the level of additives as compared to
Table 7. Average yield of fresh weight of plants depending on the type and dose of organic additives $\left(\mathrm{g} / \mathrm{m}^{2}\right)$.

\begin{tabular}{|c|c|c|c|c|c|}
\hline \multirow{2}{*}{$\begin{array}{c}\text { Dose } \\
\mathrm{w} \% \mathrm{v} / \mathrm{v}\end{array}$} & \multicolumn{5}{|c|}{ Organic additive } \\
\cline { 2 - 6 } & OB & PP & OK & T & Average \\
\hline 0 & 333 & 334 & 330 & 335 & 333 \\
\hline 4 & 491 & 386 & 401 & 360 & 409 \\
\hline 8 & 584 & 417 & 473 & 366 & 460 \\
\hline 12 & 667 & 452 & 510 & 379 & 502 \\
\hline Average & 519 & 397 & 428 & 360 & 426 \\
\hline & & & 2014 & & 190 \\
\hline 0 & 215 & 210 & 216 & 121 & $397 *$ \\
\hline 4 & 627 & 294 & 269 & lack of plants & $459^{*}$ \\
\hline 8 & 754 & 320 & 302 & $\ldots$ & $512^{*}$ \\
\hline 12 & 861 & 339 & 337 & & 395 \\
\hline Average & 614 & 291 & 281 & - & \\
\hline
\end{tabular}

$\mathrm{NIR}_{0,05}$ in 2013 : I (organic additive) - 30,

II (dose of additives) - 26, I x II - 51

NIR $_{0,05}$ in 2014: I (organic additive) - 28, II

(dose of additives) -25 , I x II -48

cocksfoot, while other reports indicate a stronger increase in chlorophyll content under the influence of nitrogen application as compared to cocksfoot [24]. This indicates specific interactions between plants and polluted soil of the landfill.

The chlorophyll A/B ratio in plant leaves was the result of genetic traits of the varieties, while type and dose of organic components slightly affected their inter-relations. Leaves of legume lupine and clover revealed a narrow proportion that amounted to 2.09 and 2.35 , respectively, while those of ryegrass and cocksfoot broaden to 3.35 and 4.37 , respectively, although under the influence of increasing doses of these components, a tendency to narrow at cocksfoot and broaden at ryegrass appeared (Fig. 3). The considerable surplus of chlorophyll A over chlorophyll B in leaves of cocksfoot were confirmed by the field observations upon the plant appearance that showed a specific bluish-green color.

Fresh weight of plants (calculated as the sum of two cuts for grasses and clover, as well as lupine harvested at the wax maturity stage) from the preliminary and consequent experiments were similar despite the strong object differentiation (Tables 7-8). In the first year after the application of organic additives into the PAH-contaminated ground, the plants produced an average of $426 \mathrm{~g} / \mathrm{m}^{2}$ fresh weight of aboveground parts, and plant weight increased in proportion to the introduced dose (Table 7). In objects where $12 \%$ of manure was added, weight of the aboveground parts of plants was two-fold higher, municipal sludge by about $54 \%$, substrate after champignon cultivation by $35 \%$, and sawdust by $13 \%$, as compared to 
Table 8. Average yield of fresh weight of plant species depending on the dose of organic additives $\left(\mathrm{g} / \mathrm{m}^{2}\right)$.

\begin{tabular}{|c|c|c|c|c|c|}
\hline \multirow{2}{*}{$\begin{array}{c}\text { Dose } \\
\mathrm{w} \% \mathrm{v} / \mathrm{v}\end{array}$} & \multicolumn{5}{|c|}{ Plant species } \\
\hline & Lupinus Albus & Trifolium hybridum & Lolium multiflorum & Dactylis glomerata & Average \\
\hline \multicolumn{6}{|c|}{2013} \\
\hline $\mathrm{K}$ & 134 & 495 & 312 & 390 & 333 \\
\hline 4 & 150 & 570 & 432 & 486 & 409 \\
\hline 8 & 156 & 620 & 494 & 571 & 460 \\
\hline 12 & 170 & 668 & 533 & 636 & 502 \\
\hline Average & 152 & 588 & 443 & 512 & 426 \\
\hline \multicolumn{6}{|c|}{2014} \\
\hline K & 143 & 219 & 251 & 239 & 190 \\
\hline 4 & 157 & $453^{*}$ & $400^{*}$ & $569^{*}$ & 397 \\
\hline 8 & 174 & $529^{*}$ & $452^{*}$ & $672^{*}$ & 459 \\
\hline 12 & 188 & $592 *$ & $476^{*}$ & $779^{*}$ & 512 \\
\hline Average & 165 & 448 & 395 & 565 & 395 \\
\hline
\end{tabular}

$\mathrm{NIR}_{0,05}$ in 2013: III (plant species) - 26, II x III - $51 \quad$ NIR $_{0,05}$ in 2014: III (plant species) - 28, II x III - 48

the control. The reaction of plant species to used additives and their doses was unequal. Clover was the most tolerant toward landfill ground conditions, which produced $495 \mathrm{~g}$ of fresh weight in the control object, cocksfoot and ryegrass 390 and $312 \mathrm{~g}$, respectively, while lupine was only $134 \mathrm{~g} / \mathrm{m}^{2}$ (Table 8). The reaction of clover is associated with the production of a relatively highly branched and shallow-spread root system. On the other hand, lupine in the environment even with low PAH contamination reacts with a drastic reduction in the yield of fresh weight of aboveground parts by $80 \%$ and underground by about $60 \%$, and the high nitrogen availability intensifies the negative effects of PAHs on plants [26]. A beneficial consequent effect of legume crop cultivation on soil properties, including content of organic carbon and nitrogen, and improving the functional properties due to additives applied is worth noting [27-28].

Using the highest dose of additives enhanced the fresh weight of ryegrass yield by $71 \%$, cocksfoot by $63 \%$, clover by $35 \%$, and lupine by $27 \%$ (Table 8 ). Particular attention should be paid to clover and ryegrass objects treated with $12 \%$ manure, where the highest amounts of fresh weight were achieved: 920 and $797 \mathrm{~g} / \mathrm{m}^{2}$, respectively, which makes up the gains by $88 \%$ and $102 \%$ in reference to the control.

In the consequent experiment, average yield of fresh weight of plants was slightly lower, while in the control without organic additives application it was reduced to 190 $\mathrm{g} / \mathrm{m}^{2}$, making $57 \%$ of the yield for control in the preliminary experiment (Table 7). This indicates the presence of the yield-forming potential of the ground, where studies were carried out, and which was remarkably diminished in the consequent experiment. It should be emphasized that 2014 was characterized by a higher quantity of rainfall and their good distribution during vegetation season, which no doubt affected the level of achieved yields of aboveground parts of plants.

The fresh weight yield harvested in 2014 depended on the type and dose of organic additives used for the reduction of $\mathrm{PAH}$ contamination. On plots with $12 \%$ manure addition, it increased up to $861 \mathrm{~g} / \mathrm{m}^{2}$ against $215 \mathrm{~g} / \mathrm{m}^{2}$ in control object, with the addition of subsoil after champignon cultivation to $339 \mathrm{~g} / \mathrm{m}^{2}$ and municipal sludge to $337 \mathrm{~g} / \mathrm{m}^{2}$ (Table 7). Applied additives did not uniformly affect plant vegetation in proportion to the introduced dose. The most efficient appeared to be bovine manure, the action of which consisted in improving the physical and biological properties of the ground, as well as introducing particular amounts of readily available nutrients. In objects with $12 \%$ manure, the quantity of introduced nitrogen and phosphorus amounted to $266.4 \mathrm{~kg}$ $\mathrm{N}$ and $64.8 \mathrm{~kg} \mathrm{P}$ per hectare. They provided an intensive growth of plants and produced relatively high yields of fresh weight of plants during the year of use and even more in consequent experiments.

Perennial plants in a control object produced similar weight of aboveground parts from 219 for clover, through $251 \mathrm{~g} / \mathrm{m}^{2}$ for ryegrass, to a slightly lower $143 \mathrm{~g} / \mathrm{m}^{2}$ for lupine (Table 8). Applying the highest rate of organic additives into ground polluted with PAHs increased the yield of fresh weight of cocksfoot by $226 \%$, clover by $170 \%$, ryegrass by $90 \%$, and lupine by only $31 \%$. Cocksfoot and clover yielded particularly abundantly on plots with $12 \%$ manure addition; these plants produced 1,233 and $1,168 \mathrm{~g} / \mathrm{m}^{2}$ of fresh weight of aboveground parts, respectively.

The yield-forming effect due to the use of organic additives depended on their type, level, and plant species (Tables 9-10). In this respect manure was outstanding, municipal sludge and subsoil after champignon cultivation 
Table 9. Effectiveness of application of $1 \%$ particular organic additives measured as an increase in mean yield of plants $\left(\mathrm{g} / \mathrm{m}^{2}\right)$.

\begin{tabular}{|c|c|c|c|c|}
\hline Interval & OB & PP & OK & T \\
\hline \multicolumn{5}{|c|}{ Preliminary experiment } \\
\hline $0-4$ & 39.5 & 13.0 & 17.7 & 6.2 \\
\hline $4-8$ & 23.2 & 7.7 & 18.0 & 1.5 \\
\hline $8-12$ & 20.7 & 8.7 & 9.2 & 3.2 \\
\hline \multicolumn{6}{|c|}{ Consequent experiment } \\
\hline $0-4$ & 103.0 & 21.0 & 13.2 & lack of plants \\
\hline $4-8$ & 31.7 & 6.5 & 8.2 &, \\
\hline $8-12$ & 26.7 & 4.7 & 8.7 &, \\
\hline
\end{tabular}

were characterized by lower efficiencies, and sawdust was very low. The most effective additives occurred at the lowest doses. In the case of manure at $4 \%$, the average efficiency of the use of $1 \%$ caused the increase in fresh plant weight in a preliminary experiment by $39.5 \mathrm{~g} / \mathrm{m}^{2}$ and by $103 \mathrm{~g} / \mathrm{m}^{2}$ in the consequent experiment (Table 9). Among tested plants, the highest efficiency of $1 \%$ additives was recorded in the consequent experiment within $0-4 \%$, and gain of the fresh weight of cocksfoot was $82.5 \mathrm{~g} / \mathrm{m}^{2}$, clover $58.5 \mathrm{~g} / \mathrm{m}^{2}$, ryegrass $37.2 \mathrm{~g} / \mathrm{m}^{2}$, and lupine $3.5 \mathrm{~g} / \mathrm{m}^{2}$ (Table 10).

In pot experiments involving alfalfa and manure addition to reduce the PAH contents, Zhang et al. (2012) reported the highest efficiency within the range of $0-1 \%$, while in an experiment with sewage sludge within $0-2 \%$ [15-16]. Growing perennial plants in an environment polluted with PAHs in combination with cutting their aboveground parts, according to Olson et al., stimulates the development of root systems and accelerates PAH reduction [12,]. Test plants (clover and perennial grasses) remaining in the ground of the landfill polluted with PAHs, show the ability to phyto-remediation, probably due to arbuscular mycorrhiza. They confirm the reaction of

Table 10. Average effectiveness of application of $1 \%$ additives (three components) measured as a yield weight of test plants $\left(\mathrm{g} / \mathrm{m}^{2}\right)$.

\begin{tabular}{|c|c|c|c|c|}
\hline Interval & $\begin{array}{c}\text { Lupinus } \\
\text { albus }\end{array}$ & $\begin{array}{c}\text { Trifolium } \\
\text { hybridum }\end{array}$ & $\begin{array}{c}\text { Lolium } \\
\text { multiflorum }\end{array}$ & $\begin{array}{c}\text { Dactylis } \\
\text { glomerata }\end{array}$ \\
\hline \multicolumn{5}{|c|}{ Preliminary experiment } \\
\hline $0-4$ & 4.0 & 18.7 & 30.0 & 24.0 \\
\hline $4-8$ & 1.5 & 12.5 & 15.5 & 21.2 \\
\hline $8-12$ & 3.5 & 12.0 & 9.7 & 16.2 \\
\hline \multicolumn{5}{|c|}{ Consequent experiment } \\
\hline $0-4$ & 3.5 & 58.5 & 37.2 & 82.5 \\
\hline $4-8$ & 4.2 & 19.0 & 13.0 & 25.7 \\
\hline $8-12$ & 3.5 & 15.7 & 6.0 & 26.7 \\
\hline
\end{tabular}

endophytic fungus infected with tall and meadow fescue, as well as alfalfa plants infected with arbuscular fungi used for phyto-remediation of soils contaminated with PAHs. Such infected plants had accelerated growth, increased the amount of produced biomass, and strongly reduced PAH content [29-31]. Also, the addition of microbiological preparations reduces the toxic action of PAHs, which was proved in the pot studies using pea, in which PAH content was reduced by $60 \%$ in two months [32].

\section{Conclusions}

1. Use of manure on the landfill ground after ozokerite mining and processing accelerated the vegetation of plant seedlings relative to the control by seven days, and subsoil after champignon cultivation and municipal sewage sludge by three days (in proportion to the introduced dose). Moreover, the additives increased plant density. The application of sawdust had no impact on plant growth rate at that phase and invoked a slight regress in the number of plants per plot.

2. Young plants in the preliminary experiment due to applied components $(\mathrm{OB}>\mathrm{PP}>\mathrm{OK})$ showed higher growth dynamics and a longer vegetation period. The consequent effect of these additives (OB, PP, and OK) on plant vegetation was weaker. The use of sawdust caused losses in all plant species during winter.

3. In the consequent experiment, the yield of green matter of aboveground parts of test plants corresponded to the type and dose of organic additives and is a good indicator of their phyto-remediation abilities. The largest weight of aboveground parts was achieved on the landfill ground treated with $12 \%$ of manure for growing the cocksfoot and pink clover.

\section{Acknowledgements}

The study was conducted with funding from the CrossBorder Cooperation Programme PL-BY-UA 2007-2013, grant agreement: IPBU 03.01.00-18-629/11-00.

\section{References}

1. PUCHALSKI CZ., WOŁOSZAŃSKA S.J., GĄSIOR J., SENKIW W. Reclamation of landfil from potassium fertilizers production in Stebnik and mining the deposit and ozokerite (earth wax) cleaning in Borysław. Wyd. KGChŚiH UR, 55, 2014.

2. MARGESIN R., SCHINNER F. Biodegradation and bioremediation of hydrocarbons in extreme environments. Appl. Microbiol. Biotechnol. 56, 650, 2001.

3. CHEN B., YUAN M. Enhanced dissipation of polycyclic aromatic hydrocarbons in the presence of fresh plant residues and their extracts. Environ. Pollut. 161, 199, 2012.

4. HU J., AITKEN M.D. Desorption of polycyclic aromatic hydrocarbons from field-contaminated soil to a two-dimen- 
sional hydrophobic surface before and after bioremediation. Chemosphere. 89, 542, 2012.

5. SWINDELL A., REID B. Influence of diesel concentration on the fate of phenanthrene in soil. Environ. Poll. 140, 79, 2006.

6. SMRECZAK B., MALISZEWSKA-KORDYBACH B. The impact of chosen grass for loss of anthracene and pyrene in soil contaminated by these compounds. Zeszyty Post. Nauk Roln. 492, 329, 2003 [In Polish].

7. GAŁĄZKA A., KRÓL M.,PERZYŃSKI A. Bioremediation of crude oil derivatives in soils naturally and artificially polluted with the use of maize as the test plant. Pt.1, PAHs degradation. Acta Scientiarum Polonorum. Agricultura. 9 (3), 13, 2010.

8. GAŁAZZKA A., KRÓL M., PERZYŃSKI A. The efficiency of rhizosphere bioremediation with Azospirillum sp. and Pseudomonas stutzeri in soils freshly contaminated with PAHs and diesel fuel. Pol. J. Environ. Stud. 21, 345, 2012.

9. GAO Y., ZHU L. Plant uptake, accumulation and translocation of phenanthrene and pyrene in soils. Chemosphere. 55, 1169, 2004.

10. LISTE H.-H., PRUTZ I. Plant performance, dioxygenase - expressing rhizosphere bacteria, and biodegradation of weathered hydrocarbons in contaminated soil. Chemosphere. 62, 1411, 2006.

11. LISTE H.-H., FELGENTREU D. Crop growth, culturable bacteria, and degradation of petrol hydrocarbons (PHCs) in a long-term contaminated field soil. Appl. Soil Ecol. 31, 43, 2006.

12. OLSON P.E., CASTRO A., JOERN M., DUTEAU N.M., PILON-SMITS E., REARDON K.F. Effects of agronomic practices on phytoremediation of an aged PAH-contaminated soil. Journal of Environmental Quality. 37 (4), 1439, 2008.

13. WÓJCIK P., TOMASZEWSKA B. Biotechnologia w remediacji zanieczyszczeń organicznych. Biotechnologia $\mathbf{4}$, 156, 2005.

14. WYSZKOWSKI M., ZIÓLKOWSKA A. Effect of compost, bentonite and calcium oxide on content of some macroelements in plants from soil contaminated by petrol and diesel oil. Journal of Elementology. 14 (2), 405, 2009.

15. ZHANG J., LIN X., LIU W., WANG Y., ZENG J., CHEN H. Effect of organic wastes on the plant-microbe remediation for removal of aged PAHs in soils. Journal of Environmental Sciences-China. 24 (8), 1476, 2012.

16. KHAN S., WANG N., REID B.J. FREDDO A., CAI CH. Reduced bioaccumulation of PAHs by Lactuca satuva L. grown in contaminated soil amended with sewage sludge and sewage sludge derived biochar. Environmental Pollution. 175, 64, 2013.

17. FERNANDEZ-LUQUENO F., MARSCH R., ESPINOSAVICTORIA D., THALASSO F., LARA M. E. HIDALGO, MUNIVE A., LUNA-GUIDO M. L.,DENDOOVEN L. Remediationof PAHs in a saline-alkaline soil amended with wastewater sludge and the affect on dynamics $\mathrm{C}$ and $\mathrm{N}$. Science of the Total environment, 402 (1), 18, 2008.
18. KUTCHER H.R., MALHI S.S. Topography and management of nitrogen and fungicide affects diseases and productivity of canola. Agronomy Journal. 97 (2), 533, 2004.

19. OSTROWSKA A., GAWLIŃSKI S., SZCZUBIAŁKA Z. Methods of analysis and estimation of soil and plants properties. Wyd. IOŚ, 334, 1991

20. HULISZ P. Selected aspects of research of saline soils in Poland. Wyd. SOP Toruń, 40, 2007 [In Polish].

21. TRIETIAKOW H.H., KARNAUCHOWA T.B., PANICZKIN L.A. Research in plant physiology. Agropromizdat. Kijów, 269, 1990 [In Ukrainian].

22. BUJDINA T.O., ROŻOK O.F. The content of chlorophylls in leaves of climbing roses Інтродукція рослин, 2, 95, 2014 [In Ukrainian].

23. MAŁACHOWSKA-JUTSZ A., MIKSCH K. The influence of rhizosphere of plants on removal of PAH, TPH and heavy oil fractions from soil. Zesz. Nauk. Politech. Śl. Inż. Środ. 45, 75, 2000 [In Polish].

24. KSIĘŻAK J., KAWALEC A. Plonowanie łubinu białego w zależności od intensywności ochrony i udziału w zmianowaniu. Prog. Plant Protection/Post. Ochr. Roślin 46, 44, 2006.

25. OLSZEWSKA M. Effects of nitrogen fertilization on physiological processes, leafgreenness index and yields of orchard grass and perennial ryegrass. Grassland Science in Poland. 9, 151, 2006.

26. WYSZKOWSKA J., KUCHARSKI J. The biochemical properties of soil contaminated by diesel oil and the yield of yellow lupine. LV (1), 299, 2004 [In Polish].

27. HAJDUK E., KANIUCZAK J., SZPUNAR-KROK E. Content of organic carbon in brown soil made of loess after cultivation of papilionaceous plants. Acta Carpathica. 3, 25, 2013.

28. GA_SIOR J. Improvement of light soil properties in result of various mineral supplements application. Wyd. UR Rzeszów, 99, 2009.

29. SOLEIMANI M., AFYUNI M., HAJABBASI M.A., NOURBAKHSH F., SABZALIAN M.R., CHRISTENSEN J.H. Phytoremediation of an aged petroleum contaminated soil using endophyte infected and non-infected grasses. Chemosphere. 81 (9), 10840, 2010.

30. ZHANG J., YIN R., LIN X., LIU W., CHEN R., LI X. Interactive Effect of Biosurfactant and Microorganism to Enhance Phytoremediation for Removal of Aged Polycyclic Aromatic Hydrocarbons from Contaminated Soils. Journal of Health Science. 56 (3), 257, 2010.

31. GAO Y., LI Q., LING W., ZHU X. Arbuscular mycorrhizal phytoremediation of soils contaminated with phenanthrene and pyrene. Journal of Hazardous Materials. 185 (2-3) 703, 2011.

32. KARPENKO O., BANYA A., BARANOV V., NOVIKOV V., KOŁWZAN B.A. Influence of Biopreparations on Phytoremediation of Petroleum-Contaminated Soil. Polish Journal of Environmental Study. 24 (5), 2009, 2015. 